\title{
8 Empirical Research and Paremiological Minimum
}

\subsection{What a Paremiological Minimum Ought to Be?}

Paremiology is researching the origin, development and the existence of paremies, i. e. proverbs, folk and weather sayings and riddles.Attempts to establish a paremiological minimum have still been oriented on the concept of the set of proverbs that all members of society know or an average adult is expected to know. So the concept of paremiological minimum has been in fact reduced to proverbs, which an average adult is expected to be familiar with. Thus, the proper term used should be the proverbial minimum. The traditional methods used to elicit answers from informants are based on the lists of proverbs or proverb beginnings and informants are asked to state their active or passive knowledge or add the missing part. Another method used is to list all the proverbs which could informants think of during a certain period.

One of the first scholars who used demographic methods with proverbs was the American sociologist William Albig (1931). 68 university students were asked to list all the proverbs they could think of during a thirty minute period. A total of 1443 proverbs were written down, out of which 442 were different proverbs (Albig, 1931: 532).

The concept of paremiological minimum was first developed by Grigorij Permjakov (1973, 1982). The spontaneous question "And what is then a paremiological maximum?" couldn't be answered reliably at least due to following reasons. Firstly, there are different opinions what a proverb is, what the boundaries of it in comparison to other types of multiword units and other fixed sentences are, secondly there are no comprehensive collections or exhaustive demographic investigation of all proverbs in a language. The biggest proverb collections include as a rule a mixture of all types of fixed phrases from different historical periods. The author of the biggest collection of German proverbs Karl Friedrich Wilhelm Wander included in his work Das Deutsche Sprichwörter-Lexikon (1867) ${ }^{127}$ more than 250000 items. Valerij Mokijenko estimates the number of proverbs in Russian at more than 150000 items (Mokijenko, 2012: 81).

The demographic attempts have still been limited to small samples of items examined by small numbers of informants, not representative regarding age, sex, regional and educational dispersion of the population. Gregorij Permjakov ${ }^{128}$ conducted in 1970s paremiological experiments to find out the minimum set of Russian proverbs that all people know. A group of informants living in and near Moscow were

127 http://de.wikipedia.org/wiki/Wanders_Deutsches_Sprichw\%C3\%B6rter-Lexikon 128 See the detailed bibliography of G. L. Permjakov`s work in Grzybek, 1984. 
supposed to mark unknown proverbs from the list of 1491 items. The other group of 100 informants had to complete the rest of the first part of a proverb. The base for the minimum consisted of 538 proverbs with the average knowledge more than $90 \%$. Permjakov set the first 500 proverb as the paremiological minimum, which have been later reduced at 300 items for smaller bilingual paremiological dictionaries, e. g. Russian-German (Permjakov, 1985) and Russian-Bulgarian (Permjakov \& Vlachov, 1986).

Paremiological minima have been done for some other languages as well. The Czech paremiological minimum by Schindler (Schindler, 1993) is based on a list of proverb beginnings to which informants were asked to add the missing part. F. Čermák, the author of another paremiological minimum of Czech, criticizes this approach of Schindler naming following problems: "The problem is, where does this list come from and on what basis is it based and selected, since, obviously, one cannot go out asking people to answer several thousand questions, i.e. the full list based on a large proverb dictionary. The second problem is more subtle. Due to linear character of our speech, it is obvious that it is the beginning of one's speech, rather than its end, which should be used in the elicitation method and suggested to in such a research" (Čermák, 2003: 15). A third point named by Čermák is that "the enquete method strives to arrive at what is usually termed as knowledge of proverbs. However, it is not quite clear, unless this is explicitly and carefully investigated by the questionnaire, what this boils down to. Does this mean an active or a passive knowledge, to what degree in the latter case and how reliable are the answers obtained" (Čermák, 2003: 16)?

An alternative approach to get a paremiological minimum of Czech by Čermák is based on examination of very large corpora. F. Čermák sees the enormous advantage in researching the proverb use in actual contexts, what makes it possible to see, document and study full variability of proverbs, which has not been possible before (Čermák, 2003: 16f). His research has been based on a large paremiological data-base, assembled for over 15 years. 243 frequent proverbs have been tested against the 100 million words of the Czech National Corpus ${ }^{129}$. This paremiological minimum contains the first 100 most frequent proverbs of the Corpus (see Čermák, 2003: 26-30).

The research on the familiarity of English proverbs is discussed by Wolfgang Mieder in his study Paremiological Minimum and Cultural Literacy (1994). Regarding the Anglo-American scene he states a meager stage of establishing the paremiological minimum; "it will require much work before this scholarly dream becomes reality" (Mieder, 1994: 307). The same conclusion is made by Heather Haas in her study about familiarity of proverbs in the United States (Haas, 2008: 319$)^{130}$. She also summarizes

129 http://korpus.cz/

$130 \mathrm{http} / /$ www.jstor.org/discover/10.2307/20487611?uid=3739024\&uid=2129\&uid=2\&uid=70\&uid=4 \&sid=21102 694102223 
the previous works on proverb familiarity and the paremiological minimum in the United States (Haas, 2008: 323-328).

An attempt to establish a kind of minimum of cultural knowledge of Anglo-American proverbs for the average educated person was using the list of 265 proverb published in Dictionary of Cultural Literacy: What Every American Needs to Know (Hirsch \& Kett \& Trefil, 1988) based on previous Hirsch`s analysis of national periodicals (Hirsch, 1987). He reasoned that if a major daily newspaper refers to an event, person or thing without defining it, he assumes that the majority of the readers will know what that item is. As Mieder notes, that Hirsch does not state how he came up with his list and he doubts that Hirsch got all of these texts out of newspapers or magazines. It says nothing about the general frequency of appearance of any item (Mieder, 1994: 309).

Mieder's set of high frequent proverbs is based on his previous archive sample of 1200 proverbs of the historical English and Anglo-American proverb collections which was compared with the large collection from Barlett J. Whiting Modern Proverbs and Proverbial Sayings (1989) containing more than 5500 entries based on materials from over 6000 books, and countless magazines and newspapers. This small list contains 33 proverbs with more than 13 references in observed texts (Mieder, 1994: 311-312).

In the research of proverb familiarity and cross-regional comparisons of the paremiological minimum in the United States made by Haas, college students from four regions of the United States completed the so called proverb generation task and a proverb familiarity rating task to determine "which texts from former generations are still current today" and "how familiar" people are "with proverbs today" (Haas, 2008: 329). In the generation task, students listed as many proverbs as they could think of "off the top of their heads" during a twenty-minute or twenty-five-minute recall period. Only 20 proverbs were generated by more than $10 \%$ of 156 respondents. In the proverb familiarity task, 193 students indicated their familiarity with 315 proverbs included because previous researchers had identified them as being relatively familiar or common. The proverbs were rated on a 4-point scale, in which the rating categories were defined as: 1 . Not at all familiar: "I have never heard this phrase in this form before.”, 2. Slightly familiar: "I believe I have encountered this phrase in this form before, although not often.", 3. Moderately familiar: "I encounter this phrase occasionally. I'm sure I've heard it several times before.”, 4. Very familiar: "I encounter this phrase quite frequently; I've heard it on numerous occasions.” (Haas, 2008: 330). The optimistic conclusion of this study is that a truly national paremiological minimum may well be achievable because of clear evidence that proverbs familiar in one region can generally be expected to be familiar in other regions as well (Haas, 2008: 319). We fully agree with the statement of Haas that there is no right research method any more than there is a right informant or research sample (Haas, 2008: 335).

There are also different attempts to establish paremiological minima for German language. The paremiological minimum from Grzybek (1991) contains 77 and in 
Chlosta \& Grzybek \& Roos (1994) 65 items, and was based on achievement testing method of completing the missing parts of 275 proverbs through 125 respondents.

Our research of German proverbs is based on the competence test correlated with corpus based examination of the text frequency of proverbs from standard lexicographic sources (Ďurčo, 2001, 2002, 2003, 2005a, 2006). The familiarity of 385 proverbs is based on questionnaire data by 220 informants from Germany, Austria a Switzerland $^{131}$, which were tested for their frequency in DeReKo ${ }^{132}$. We have discovered that the proverbs most frequently used in everyday speech do not have necessarily the same status as the proverbs most used in published writing. In contrast to the concept of paremiological minimum we prefer the concept of a paremiological optimum ${ }^{133}$. Our paremiological optimum of 150 proverbs is than a correlation of the most familiar proverbs with the highly frequented proverbs in corpus. A paremiological minimum is then a set of proverbs based on empirical demoscopic research that only a specific group of informants knows or is familiar with.

A set of highly frequented proverbs by Steyer (2012a) is also based on the corpus analysis. There were 1000 traditionally lexicographic registered proverbs tested in DeReKo. The outcome of this corpus analysis was a list of 300 most frequent proverbs. This set of proverbs was used as a base for the elaboration on principles of digital multilingual paremiography (Ďurčo \& Steyer, 2010; Steyer \& Ďurčo, 2013; Steyer \& Hein, 2010) in the EU-project SprichWort-Plattform ${ }^{134}$. The results of the project were published in Steyer (2012b). Paremiological experiments to paremiological minima exist also for Hungarian (Tothné Litovkina, 1996; Vargha \& Litovkina, 2007) and Croatian (Grzybek \& Škara \& Heyken, 1993).

\subsection{Why Do We Need a Paremiological Minimum or Optimum?}

The long history of the existence and lexicographic registration of proverbs lead scholars to considerations of their development, presence and occurrence in everyday use in the current language. The visionary program and methodological approach for such a research has been defined by Matti Kuusi, one of the leading scholars in the field of paremiology: "What is now needed is for a team of scholars from such

131 In this attitude test the informants should grade on a four-level scale (1. Known and used, 2. Known but not used, 3. Unkown, but understandable, 4. Unknown und not understandable) their knowledge or familiarity of a proverb.

132 http://www1.ids-mannheim.de/kl/projekte/korpora/

133 The concept of a paremiological optimum is based on the correlation between the best known proverbs by users and thier high frenquency in text corpora, see the Part 4.

134 EU-Projekt SprichWort. Eine Internetplattform für das Sprachenlernen (2008-2010, 143376-LLP1-2008-1-SI-KA2-KA2MP). 
disciplines as folklore, linguistics, sociology, psychology, anthropology, paremiology, and demography to work out an even more elaborated questionnaire to be used with several thousands [...] citizens. The result of such an integrated study would in true give us a precise idea of how proverbs are used and viewed today and which proverbs belong to the [...] paremiological minimum. Once national paremiological minima are established we will also be able to determine the most frequently used international proverb types through comparative proverb collections. Such work will eventually lead to an international paremiological minimum for the world's proverbial wisdom" (Kuusi, 1985: 22-28).

A skeptical position to establish an ideal common paremiological minimum is held by Mokijenko. He states that the concept of a common paremiological minimum is not realistic. There exists a certain zone of familiar proverbs only, which comprise a core of national paremiology. But this core is very variable and differentiated among people. It depends on the particular social factors like age, education, origin, but also on the individual preferences of speakers, what discourages the determination of a general valid common paremiological core (Mokijenko, 2012: 83f).

Despite this skeptical and pessimistic opinion the fact is that proverbs are effective verbal devices and we must have a certain paremiological optimum at our disposal in order to participate in meaningful communication. Such an optimum has its obvious benefits for mono- and bilingual paremiography and paremiodidactics as well. The most frequently used proverbs of the modern age in spoken and written communication should be included in various dictionaries and textbooks. It means that we need not only one paremiological minimum, but various specific minima for teaching mother tongue and foreign languages on different levels. We also need a common set of proverbs for culturally literate and effective communication of the average educated person as well, which could be considered as a paremiological optimum.

\subsection{How to Get a Paremiological Optimum? An Empirical Approach}

The scholars' common opinion is that the study of a today's paremiological minimum of any group of people must be based on scientific demographic research. The problem is how to get a core set of proverbs for such demographic research?

The ways how to get such a sample are:

- Excerption from texts (from fiction, non-fictional and journalistic texts)

- Excerption from dictionaries and proverb collections (from historical and contemporary periods)

- Analysis of corpora (through the examination of the frequency of proverbs in very large or huge corpora) 
- Direct observation (through a long-term observation and archiving the proverbs from everyday spontaneous and spoken-media communication).

Each method has its advantages and limits and brings heterogeneous or even antagonistic results. It means that we need different methodological approaches which will meet all methodological requirements and cover all aspects and characteristics of proverbs. The methods have to be seen not as contradictory but complementary attempts how to get real and objective data about the observed material.

Empirical research should give answers at least to the following questions:

1. Which proverbs from former generations are still in use today?

2. How familiar are people with proverbs today?

3. Which proverbs traditionally registered in contemporary dictionaries belong to the active and passive vocabulary of persons?

4. Which of them are not used by people nowadays?

5. Are there differences in the familiarity of proverbs regarding age, sex, regional and educational background?

6. What is an individual's score of paremiological competence compared with the overall paremiological competence of all informants?

7. In which form do traditional proverbs exist today?

8. Which are the truly new proverbs of the modern age? (Mieder, 1994: 299).

This sociologically and linguistically oriented catalogue of questions ought to be extended with no less important psychological aspects, i.e. how people acquire, use and interpret proverbs, idioms and figurative language in general in everyday communication (e. g. Buhofer, 1980; Häcki Buhofer, 1989, 1997, 1999; Häcki Buhofer \& Burger, 1992, 1994; Ďurčo, 1990, 1992, 1998; Everaert et al, 1995; Cacciari \& Glucksberg, 1991; Cacciari \& Tabossi, 1993; Gibbs, 1985; Gibbs \& Nayak, 1989; Gibbs \& O`Brien, 1990).

The attempts to testing knowledge or familiarity of proverbs may be prescriptive (the informants judge the prepared lists of proverbs, which they should know) or descriptive (free observation of spontaneous elicitation of proverbs, which people are really familiar with). There are six types of testing methods used as a rule to examine the paremiological competence of informants.

1. Competence tests. Informants should mark known and unknown proverbs from a list.

2. Achievement tests. Informants should complete the missing part of a proverb.

3. Introspection tests. By these self-reporting tests informants should write down spontaneously within a certain period of time all the proverbs which they use or know.

4. Attitude tests. This tests uses attitude scales to determine individual and group preferences for proverbs. Informants should grade on a scale their knowledge or familiarity of a proverb. 
5. Cognitive tests. In this free response tests informants should interpret the meaning of proverbs to prove their active knowledge of it.

6. Experience tests. Informants should comment, if, when and how do they and/or other people use proverbs.

The paremiological experiments still used, however, do not meet the substantial methodological principles of testing, such as standardization, objectivity, comparability, reliability and validity because of low sociolinguistic representativeness accompanied with arbitrary compiled lists of examined proverbs without sufficiently defined selection criteria ${ }^{135}$.

The measurability of the knowledge or familiarity of proverbs shouldn't be in principle questioned, however the critique concerns the creation of the experimental set of proverbs in due to subjective and intuitive estimations of paremiologists and paremiographers creating their experimental lists (Grzybek \& Chlosta, 1993: 113). As problematic also appear the justification and drawing up of the limits for what is a general or common knowledge (see Chlosta \& Grzybek, 1997: 244). Permjakov sees the limit for the common knowledge by $97 \%$, Grzybek by $95 \%$ and Schindler by $90 \%$. But we may also set the limit for the average knowledge by $50 \%$, if we would obtain the data from a sociolinguistically reliable and representative demoscopic research of the population.

Critique concerns also the weak procedure of the presentation of the prescribed form of proverbs in experiments due to lack of information what the standard variant of a proverb really is (Chlosta \& Grzybek, 1997: 257). Grzybek sees in the checking of predefined answers also the danger of defective intuitive assessment of informant supposing he knows the proverb (Grzybek, 1998: 114).

We obtain also very different results by using active (to elicit the spontaneous reaction) or passive (to check prescribed answers) testing procedures. L. Cox (1997) has discovered in his experiments that the overall paremiological thesaurus of students is very low, i.e. the number of identic elicited proverbs is not very high, but the individual paremiological thesaurus, i. e. the whole number of all individually elicited proverbs from all informants, is very high. ${ }^{136}$ This can be an evidence that the active and passive paremiological competence is not only much higher as an experiment can find out but also it is the evidence that the acquisition, usage and understanding of proverbs in semantic memory by an individual person proceed very differently and the information is coded and stored unevenly (Cox, 1997: 45). In contrast

135 See the detailed discussion and critique of empirical paremiology, paremiological experiments and testing methods in Grzybek \& Chlosta (1993), Chlosta \& Grzybek (2004); Grzybek (2012).

136 In the experiment by Cox 229 informants have elicited spontaneously 232 proverbs, in the next experiment were the students asked to register during a week all proverbs which come to mind. 42 informants registered 1250 different proverbs. 
to passive experiments, where the knowledge of $100 \%$ was very often registered, the active experiments deliver as a rule only an overall knowledge of $30 \%$.

Despite all this problems the empirical experiments may deliver relevant sociolinguistic information not only about the territorial, age specific and culturally bound status of proverbs but also data to their actual status and changes in current habitual language use. The paremiological experiments help us to examine the paremiological competence, which is the active and the passive knowledge of proverbs by an individual elicited through a paremiological experiment and also the paremiological performance which is the active and the passive overall knowledge of proverbs by all informants in a paremiological experiment.

The way out in order to overcome the dilemma between methodological requirements and feasibility of paremiological experiments consists in testing nationwide groups of persons, and in the frequency analysis of huge written and spoken corpora (Grzybek, 1992: 211; Grzybek \& Chlosta, 1993: 96). The open problems are still the reduction of large lists of proverbs and the demoscopic representative sample of respondents. It is not possible and also not reasonable to distribute big paremiological samples among respondents.

\subsection{The Concept of a Paremiological Optimum. A Complex Approach}

Defining research objective is the most exacting step in designing a research plan. One of the ways how to get a more accurate picture reflecting the reality is to use a combination of multiple research methods. Paremiological research may also benefit from such a combination of introspective (induction, deduction, synthesis) and empirical methods (demographic research, psycholinguistic experiment, an extensive analysis of corpora, statistics), in particular where answers are required to the questions as follows:

- Which paremiological elements included in collections as a standard set are part of an active or a passive vocabulary of language users?

- What is the degree of matching between the presented standards and the individual or common usage, to what extent the users accept these standards when speaking, and to what extent the current linguistic or lexicographic description matches the reality?

- What are the differences in awareness of linguistic phenomena and their usage when taking account of the age of language users, their educational background and the region where they live?

Such combined analysis was employed in our research into the Slovak paremiology (Ďurčo, 2004, 2005b, 2005c, 2007). It was undertaken to ascertain the level of 
awareness of traditional paremiological units currently registered in lexicographic collections. Our goal was to find out which paremiological units registered in lexicographic collections are currently really familiar to Slovak language users and actively used by them.

It is not possible to investigate all proverbs with their numerous variants so it is reasonable to desist from the extensive empirical research. A compromise solution is the reduction of the material for the experimental corpus in the following five steps.

1. Analysis of the lexicographic registration of proverbs in older and current dictionaries.

2. Determination of the core set of proverbs and their basic forms through the reduction of the paremiological material by the expert's knowledge of linguists, lexicographers, paremiologists and ethnologists.

3. Analysis of the knowledge and familiarity of the selected proverbs and their variants by respondents through an on-line questionnaire.

4. Analysis of the occurrence of the preferred proverbs from questionnaires and their variants in huge corpora.

5. The comparison and correlation of the most familiar proverbs with the most frequent proverbs in corpora.

The same method has been used as well for the Slovene language (Meterc, in press), what has enabled to compare formal, semantic and suprasemantic (diasystemic) equivalency of Slovak and Slovene proverbs on the identical empirical and methodological basis (Ďurčo \& Meterc, in press). The empirical and corpus based research allows a fully new approach to comparison and typology of equivalence of in paremiology (Ďurčo, 2012, 2013) and to the typology of variability of proverbs (Ďurčo, 2008).

\subsection{An Example: Paremiological Optimum of Slovak Language}

\subsubsection{Method}

The research consisted of five phases: 1 . Selection of a data set and design of a questionnaire, 2. Reduction of the core set of proverbs through experts, 3. Questionnaire survey to determine commonly known proverbs, 4. Frequency analysis of the best known proverbs in the Slovak National Corpus, 5. Creation of a paremiological optimum. To make a survey more effective, an electronic version of the questionnaire was elaborated, as an online Access application. The questionnaire is available at www.reflectangulo.net/index.php?loc=fraz and enables the users to upload it. This website also provides all the information on how to install the programme, fill in the questionnaire and how to send it via Internet. 
An initial form necessary to be filled in to start the corpus includes the following metadata concerning a respondent: age, gender, education, dialect regions where the respondent was grown up and where he currently lives. After filling in the initial form and submitting a password chosen by the respondent, the questionnaire will start.

Formulating the questions and a way to elicit responses are crucial questionnaire design issues. Due to an extensive nature of examined data, the formulation of offered responses should have been as simple as possible to elicit spontaneous responses. The programme offers, inter alia, an option of interrupting the questionnaire at any time. The screen always shows one item only - a particular proverb, and a respondent is required to assign one of the offered responses to it:

1. I know and I use the proverb.

2. I know, but I do not use it.

3. I do not know the proverb, but I understand it.

4. I do not know the proverb and I do not understand it.

Respondents have also the fifth option, namely giving their own wording of the proverb which is at variance to that given in the questionnaire. In addition, the programme enables the change of response to any previously listed proverb. At the end, the respondent may give any other proverbs he knows and uses although not listed in the questionnaire.

\subsubsection{Questionnaire}

The questionnaire consists of 2834 items. The data set used in this questionnaire survey was created on the basis of following sources: The Selection of Proverbs and Sayings from the Collection of A. P. Záturecký (it includes 13000 units) made by prominent Slovak experts in phraseology and paremiology, a linguist J. Mlacek and an ethnologist Z. Profantová (1996). The authors selected approximately 3000 units from the Záturecký's collection that, in their opinion, are of certain relevance for current language users; proverbs entered in a phraseological dictionary by E. Smiešková (1977); proverbs included in a current normative dictionary Krátky slovník slovenského jazyka (Kačala \& Pisárčiková, 2003), and also proverbs quoted in the publication Miko et. al. (1989). This particular publication includes all the idioms and proverbs that occurred in the textbooks for elementary and secondary schools in Slovakia in the seventies through nineties, thus the children had heard, read or used them. Our experimental questionnaire was drawn up using all the above sources. Numerous variants of the same proverbs differing only in an initial pronoun, word order or lexicon were unified. However, the respondents were given the opportunity to write the variant of a proverb familiar to them. The steps described above resulted in the creation of the questionnaire corpus that reflects the topical Slovak paremiology included in current handbooks. 


\subsubsection{Empirical Survey Findings}

There were 42 respondents ( 24 women and 18 men) originated from all the regions of Slovakia. The respondents' average age was 43 years of age (men 45, women 42). Due to a relatively small number of respondents, we were unable to get relevant results in respect of familiarity of proverbs by age groups. However, an expected tendency to higher knowledge and familiarity has been registered by older informants.

The generally known and actively used common paremiological core set is relatively small. The respondents indicated just around 16\% of proverbs (including different variants) as part of their active vocabulary. A chart below shows the overall frequency for each response category:

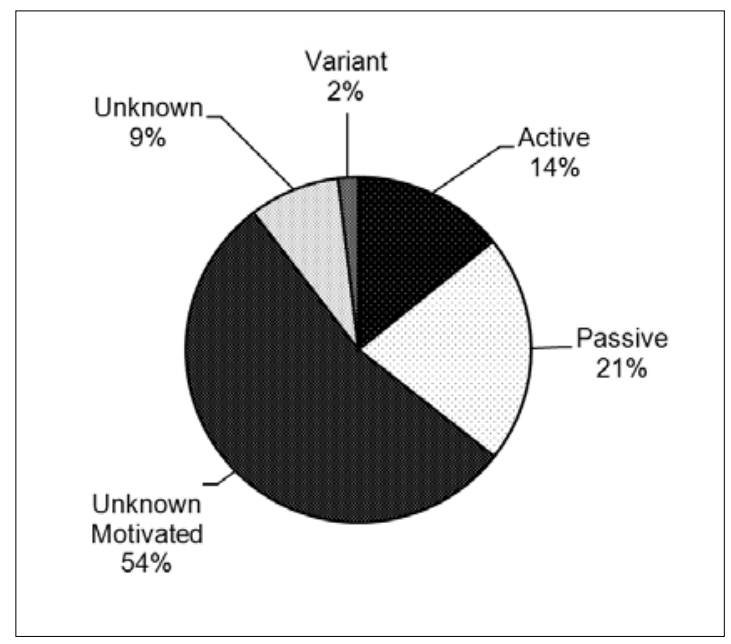

Based on the responses, five sets of proverbs have been formed. The first set consists of proverbs that the respondents indicated as part of their active vocabulary. The set of actively used ones includes approximately 250 proverbs (= active usage stated by more than $50 \%$ of the respondents), the set of familiar but not used by the respondents includes only 50 proverbs (in compliance with a criterion more than $50 \%$ of respondents). The biggest set (approx. 1900) consists of proverbs that the informants indicated as unknown, although they supposed to understand their background motivation and also their meaning. More than $50 \%$ of the respondents placed only approx. 100 proverbs, out of the total number 2834 unit, into the set of unknown and not understandable. The respondents rarely gave variants of proverbs and they accepted submitted forms without commenting on them. In our opinion, the variance issue should be more adequately and effectively examined in language corpora using the methods of corpus linguistics. 


\subsubsection{Corpus Analysis Findings}

Comparisons in the area of idiomatics show huge differences in frequency between spoken and written language. The proverbs that had been placed by the respondents into active spoken usage were therefore confronted with their occurrence in the Slovak National Corpus. ${ }^{137}$

The chart below shows a relation between the level of active usage of proverbs by the respondents (60-100\% level of knowledge or familiarity) and their absolute occurrence in the Corpus (1-195 occurrences):

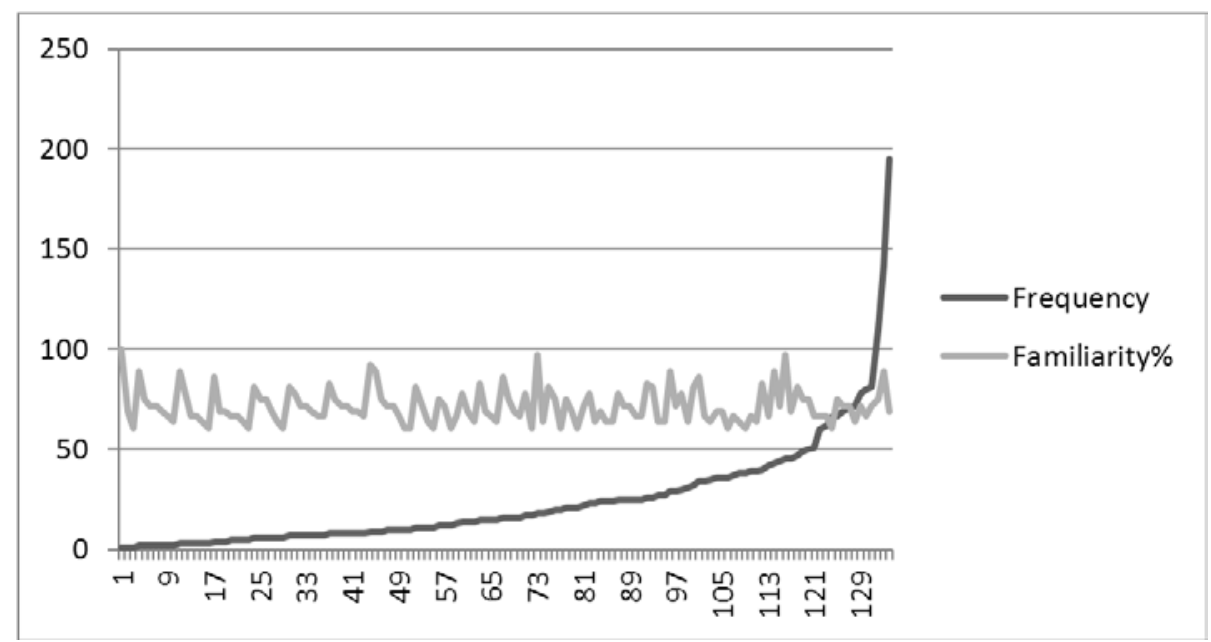

Great differences in the corpus frequency of proverbs suggest at first sight an evident disproportion among examined parameters. In order to determine the paremiological optimum, it is necessary to correlate both parameters, namely to find the top intersection of familiarity level given by speakers and the frequency of occurrence in the Corpus.

The proverbs Kto sa hanbí, má prázdne gamby. [ww: Who is ashamed, his mouth remains empty. ee: Fortune favours the brave.] My o vlku a vlk za humnami/dverami/ humny. [ww: Speak of the wolf, and the wolf is behind the barns/doors. ee: Talk of the Devil, and he is bound to appear.] Aká diera, taká záplata. [ww: Like hole, like patch. ee: Pay somebody back in his own coin.] Múdry sa nik nenarodil. [ee: No one is born a master.] have had no occurrence in the Corpus.

137 prim0.1, prim0.1-public. Slovenský národný korpus. Bratislava: Jazykovedný ústav L'. Štúra SAV 2003. WWW: http://korpus.juls.savba.sk. 
Maximum disproportions between the spoken language and the text frequency were ascertained in respect of the following proverbs. The proverbs listed below had above-average familiarity among the respondents, but below-average frequency in the Corpus:

1. Aká práca, taká pláca. [ww: You get paid as much as you deserve for your work. ee: No pain, no gain].

2. Aká otázka, taká odpoved'. [ww: Like question, like answer. ee: Ask a silly question and you get a silly answer.]

3. Kto neskoro chodí, sám sebe škodí. [ww: He who is late causes harm to himself. ee: Time and tide wait for no man.]

4. Aj zajtra je deň. [ee: Tomorrow is another day.]

5. Aj steny majú uši. [ee: Walls have ears.]

6. Ako sa do hory volá, tak sa z hory ozýva. [ww: The way you call into a forest, the way it echoes back. ee: You get as much as you give. What goes around, comes around.]

7. Nemá všetkých pohromade. [ww: He has not all (his five senses) together. ee: He hasn't got all his marbles. He's not right in the head. He is as mad as a March hire.]

8. Samochvála smrdí. [ww: Self-applause stinks. ee: Stop blowing your own trumpet!]

9. Babka k babce, budú kapce. [ww: Bob to bob, there will be felt boots. ee: A penny gained is a penny saved.]

10. Vie, odkial' vietor fúka. [ee: He knows which way the wind is blowing.]

11. Učený nikto z neba nespadol. [ww: No man has fallen from the sky learned. ee: No one is born a master.]

This list gives the most frequent occurrences in the Corpus (more than 50 occurrences):

1. Nie je všetko zlato, čo sa blyští. [ee: All that glitters is not gold.] 50

2. Dobrá rada nad zlato. [ee: A piece of good advice is better than gold.] 51

3. Nijaká kaša sa neje taká horúca, ako sa uvarí.[ww: No porridge is eaten hot when just cooked. ee: Things never are as bad as they seem.] 52

4. Škoda plakat' nad rozliatym mliekom. [ee: It is no good/use crying over the spilt milk.] 60

5. Hop alebo trop. [ee: Sink or swim. Make or break.] 62

6. Padla, trafila kosa na kameñ. [ww: The scythe has hit a stone.ee: He met his match.] 66

7. Už je ruka v rukáve. [ww: Arm is already in the sleeve. ee: To be hand in glove with sb.] 67

8. Nič netrvá večne. [ee: Nothing can last forever.] 69

9. Jablko nepadá d'aleko od stromu. [ww: The apple never falls far from the tree. ee: Like father like son. He/she is a chip off the old block.] 70

10 Oko za oko, zub za zub.[ee: An eye for an eye, a tooth for a tooth.] 72 
11. Stará láska nehrdzavie. [ww: Old love never gets rusty. ee: Old love never dies. Old love never goes cold.] 78

12. O tom už aj vrabce na streche čivirikajú. [ww: Sparrows tweet about it on the roof. ee: A little bird told me. It's an open secret.] 80

13. $S$ jedlom rastie chut'. [ee: The appetite grows with what it feeds on. The more one has, the more one wants.] 81

14. Božie mlyny melú pomaly, ale isto. [ww: The mills of God grind slowly, but surely. ee: The mills of God grind slowly.] 93

15. Účel svätí prostriedky. [ww: The purpose consecrates the means. ee: The end justifies the means.] 110

16. Prišlo na lámanie chleba. [ww: It came to breaking the bread (cutting the bread).ee: When it comes to the crunch.] 142

17. Zakázané ovocie najlepšie (najviac) chutí. [ww: Forbidden fruit tastes best. ee: Forbidden fruit is the sweetest.] 195

\subsection{Paremiological Optimum of Slovak Language - correlation of the knowledge/familiarity and the corpus frequency}

1. Zakázané ovocie najlepšie (najviac ee: chutí.) [ww: Forbidden fruit tastes best ee: Forbidden fruit is the sweetest.]

2. Prišlo na lámanie chleba. [ww: It came to breaking of bread (cutting the bread) ee: When it comes to crunch.]

3. Božie mlyny melú pomaly, ale isto. [ww: The mills of God grind slowly, but surely. ee: The mills of God grind slowly.]

4. Účel svätí prostriedky. [ww: The purpose consecrates the means. ee: The end justifies the means.]

5. $S$ jedlom rastie chut. [ee: The appetite grows with what it feeds on. The more one has, the more one wants.]

6. Stará láska nehrdzavie. [ww: Old love never gets rusty. ee: Old love never dies. Old love never goes cold.]

7. O tom už aj vrabce na streche čivirikajú. [ww: Sparrows tweet about it on the roof. ee: A little bird told me. It's an open secret.]

8. Jablko nepadá d'aleko od stromu. [ww: The apple never falls far from the tree. ee: Like father like son. He/she is a chip off the old block.]

9. Už je ruka v rukáve. [ww: Arm is already in the sleeve. ee: To be hand in glove with sb.]

10. Nič netrvá večne. [ee: Nothing last forever.]

11. Oko za oko, zub za zub. [ee: An eye for an eye, a tooth for a tooth.]

12. Bez vetra sa ani listok (list) (na strome) nepohne. [ww: No leaf /on the tree/ will move without wind. ee: There's no smoke without fire.] 
13. Hop alebo trop.[ee: Sink or swim. Make or break.]

14. Výnimka potvrdzuje pravidlo. [ee: The exception proves the rule.]

15. Škoda plakat' nad rozliatym mliekom. [ee: It is no good/use crying over the spilt milk.]

16. Padla, trafila kosa na kameň. [ww: The scythe has hit a stone / has fallen onto the stone. ee: He met his match.]

17. Nie je všetko zlato, čo sa blyští. [ee: All that glitters is not gold.]

18. Iný kraj iný mrav. [ww: Different countries, different manners. ee: When in Rome do as the Romans do.]

19. Bližšia košel'a ako kabát. [ww: The shirt is nearer to the body than the coat. ee: Charity begins at home.]

20. Trpezlivost' ruže prináša. [ww: Patience brings roses. ee: Patience is the best remedy for every trouble. Everything comes to him who waits.]

21. Každý začiatok býva t’ažký. [ww: Every beginning is always hard. ee: The first step is always the hardest.]

22. Nijaká kaša sa neje taká horúca, ako sa uvarí. [ww: No porridge is eaten hot when just cooked. ee: Things never are as bad as they seem.]

23. Bez práce nie sú koláče. [ww: There are no pies without work. ee: Success never comes easily. No gain without pain.]

24. Risk je zisk. [ww: Risk is the profit. ee: Nothing ventured nothing gained.]

25. Vodu káže a víno pije. [ee: He preaches water and drinks wine.]

26. Čert nikdy nespí. [ee: The devil never sleeps.]

27. Palica má dva konce. [ww: A stick has two ends. ee: There are two sides to everything.]

28. Nekrič hop, kým si nepreskočil. [ww: Do not say "hop” before you jump over. ee: There is many a slip twixt cup and lip.]

29. Čo je vel'a, to je vel'a. [ee: Enough is enough.]

30. Dobrá rada nad zlato. [ee: A piece of good advice is better than gold.]

31. Kto hl'adá, nájde. [ww: He who seeks, will find. ee: Seek and ye shall find.]

32. Koniec dobrý, všetko dobré. [ee: All's well that ends well.]

33. Odvážnemu štastie praje. [ee: Fortune favours the brave.]

34. Čo sa stalo, už sa neodstane. [ww: You cannot change what has already happened. ee: What's done cannot be undone.]

35. Všade dobre, doma najlepšie. [ww: Everywhere is well, at home it's best. ee: East, west, home's best.]

36. Lepši vrabec $v$ hrsti ako holub na streche. [ww: A sparrow in one hand is worth a pigeon on the roof. ee: A bird in one hand is worth two in the bush.]

37. Kto prv [ww: skôr ee: príde, ten prv [ww: skôr ee: melie. [ww: He who comes sooner shall mill sooner. ee: First come first served.]

38. Remeslo má zlaté dno. [ww: A trade has a gold bottom. ee: If you know a trade you will never starve.] 
39. Múderejší ustúpi. [ww: He who retreats is wiser. ee: Better to bend the neck than bruise the forehead.]

40. Človek mieni, Pán Boh mení. [ee: Man proposes, God disposes.]

41. Aká práca, taká pláca. [ww: You get paid as much as you deserve for your work. ee: No pain, no gain.]

42. Aj zajtra je deřn. [ee: Tomorrov is another day.]

43. Ešte nikdy nebolo tak zle, že by nemohlo byt' ešte horšie. [ww: Never was so bad, that it couldn't be worse. ee: Bad is called good when worse happens. The evil can be every time worse.]

44. Trafená hus zagága. [ww: A shot goose will make gaggle. ee: If the cap fits wear it.] 45. Ja nič, ja muzikant. [ww: I am nothing, I am a musician. ee: I have nothing to do with it.]

46. Podla seba súdim teba. [ww: I judge you by myself. ee: Don’t judge others by yourself.]

47. Reči sa hovoria a chlieb sa je. [ww: Speech is spoken and bread is eaten. ee: It's just so much hot air.]

48. Jedna lastovička leto nerobí.[ee: One swallow doesn’t make a summer.]

49. Ako sa do hory volá, tak sa z hory ozýva. [ww: The way you call into a forest is the way it echoes back. ee: You get as much as you give. What goes around, comes around.]

50. Vrana $k$ vrane sadá. [ww: A crow sits next to a crow. ee: Birds of feather flock together.]

51. Kto sa smeje naposledy, ten sa smeje najlepšie. [ww: He who laughs, last laughs the best. ee: He who laughs last laughs longest.]

52. Čas sú peniaze. [ee: Time is money.]

53. Láska hory prenáša. [ee: Love can move mountains. ]

54. Kto druhému jamu kope, sám do nej (s)padne. [ww: He who digs a pit for another falls into it himself. ee: People are often caught in their own trap.]

55. Čo sa za mladi naučíš, na starost’ a koby si našiel. [ww: What you have learnt young, you will find useful when old. ee: What's learnt in the cradle lasts till the tomb. In youth we learn, in age we understand.]

56. Nehas, čo t’a nepáli. [ww: Do not extinguish what is not burning you. ee: Don't mend what ain't broken.]

57. Ani z voza, ani na voz. [ww: Not from carriage, no on carriage. = In no way.]

58. Čo na srdci, to na jazyku. [ww: What is in the heart that is on the tongue. ee: Have one's heart in one's mouth.]

59. Nemá to ani hlavy, ani päty. [ww: It has neither head nor heel. ee: It has neither rhyme nor reason.]

60. Lož má krátke nohy. [ww: A lie has short legs. ee: A lie has no legs.]

61. Kto neskoro chodí, sám sebe škodí. [ww: He who is late causes harm to himself. ee: Time and tide wait for no man.]

62. Aký požičaj, taký vrát'. [ww: Like borrow, like repay. ee: Tit for tat.] 
63. Komu niet rady, tomu niet pomoci. [ww: You cannot help the one who does not listen to advice. ee: There's no helping those that won't help themselves.] 64. Zvyk je železná košel’a. [ww: Habit is an iron shirt. ee: Habit is second nature.] 65. Istota je istota. [ww: Safe is safe. ee: Better to be safe than sorry.] 66. Aká otázka, taká odpoved'. [ww: Like question, like answer. ee: Ask a silly question and you get a silly answer.]

67. Babka k babce, budú kapce. [ww: Bob to bob, there will be felt boots. ee: A penny gained is a penny saved.]

68. Každý chvîl'ku tahá pílku. [ww: Everybody pulls the saw just for a while. = Everybody's dominance/power is limited. ee:

69. Ked' neprší, aspoň kvapká. [ww: Even if it does not rain, at least it drips. ee: Every little bit helps.]

70. Kto chce psa bit', palicu nájde. [ww: He who wants to beat a dog finds a stick. ee: Give a dog a bad name.]

71. Strach má vel'ké oči. [ww: Fear has big eyes. ee: Fear has magnifying eyes

72. Aj steny majú uši. [ee: Walls have ears.]

73. Učený nikto z neba nespadol. [ww: No man has fallen from the sky learned. ee: No one is born a master.]

74. Vie, odkial' vietor fúka. [ee: He knows which way the wind is blowing.]

75. Nešt’astie nechodí po horách, ale po l'ud'och. [ww: Misfortunes never walk in the forest, but they happen to people. ee: Accidents will happen.]

76. Vrana vrane oko nevykole. [ww: A crow will never peck out a crow's eyes. ee: Dog does not eat dog.]

77. Samochvála smrdí. [ww: Self-applause stinks. ee: Stop blowing your own trumpet!]

78. Príde na psa mráz! [= There will be a bad outcome for him/her.]

79. Čo si kto navaril, nech si aj zje (to nech si zje). [ww: As you cooked the meal, so must you eat it. ee: As you make your bed, so you must lie on it.]

80. Dva razy meraj, raz strihaj! [ee: Measure twice, cut once! Look before you leap.]

81. Komu sa nelení, tomu sa zelení. [ww: He who is not lazy will get green. ee: The early bird catches the worm. No pain, no gain.]

82. Čo oči nevidia, to srdce nebolí. [ee: What the eye doesn't see, the heart doesn’t grieve over.]

83. Nemá všetkých (pät') pohromade. [ww: He has not all [ww: his five senses ee: together. ee: He hasn't got all his marbles.]

84. Aj malé ryby sú ryby. [ee: Even small fish are fish.]

85. Sluby sa slubujú, blázni sa radujú. [ww: Promises are promised, fools enjoy it. ee: Promises, promises!, Fine words butter no parsnips.]

86. Pomaly d'alej zájdeš. [ww: You get farther at slow pace. ee: The more haste, the less speed.]

87. Čas je najlepši lekár. [ww: Time is a best doctor. ee: Time heals all wounds.]

88. Kto mlčí, ten svedčí. [ww: He who remains silent gives his consent. ee: Silence is consent. 
89. Čas všetko zahojí/vylieči. [ww: Time heals everything. ee: Time is a great healer.] 90. Hlavou múr neprebiješ (neprerazíš). [ww: Your head won’t break a brick wall. ee: You're/ It's banging your head against a brick wall.]

91. Hovorit' striebro, mlčat zlato. [ee: Speech is silver but silence is gold.]

92. V núdzi poznáš priatel'a. [ww: In the need you know/recognise a friend. ee: A friend in need is a friend indeed.]

93. Svetská sláva - polná tráva. [ww: Wordly fame - field grass. ee: It’s just a flash in the pan. Fame is short-lived.]

94. Príležitost' robí zlodeja. [ee: Opportunity makes the thief.]

95. Ako prišlo, tak odišlo. [ee: Easy come, easy go.]

96. Kôn̆ má štyri nohy, a predsa sa potkne. [ww: The horse has four legs, but it stumbles. ee: It's a good horse that never stumbles.]

97. Vyčkaj času ako hus klasu. [ww: Wait for time like a goose for spike. ee: All in good time. Everything comes to him who waits.]

98. Darovanému koňovi nepozeraj (nehlad') na zuby. [ww: Don't look a gift horse at the teeth. ee: Don't look a gift horse in the mouth.]

99. Čo môžeš urobit’ dnes, neodkladaj na zajtra! [ee: What you can do today, never put off till tomorrow.]

100. Keby nebolo keby, boli by sme všetci v nebi. [ww: If there wasn't for the if, we would all be in heaven. ee: If it wasn't for the “ifs”, you would be rich.]

\subsection{Conclusions}

The survey like this did not offer the opportunity to ascertain whether the respondents also correctly understand the proverb. However, this fact is irrelevant for the purposes of sociolinguistics as the respondents' intuitive evaluation is significant. Future research will also have to take into account the real linguistic competence, the linguistic correctness, and also to examine the accuracy of the understanding of proverbs through cognitive tests.

Further research should focus on examining the linguistic competence by using smaller sets of selected proverbs. These tests should be based on the so-called active paremiological core set. The focus should be also given to testing the set of proverbs from the third group where the respondents were supposed to understand the proverb, due to the motivation of the units and to the respondents' intuition. When conducting this survey, different paremiological experiments should be applied, e.g. the modified Permjakov's method. For instance, in order to increase the objectiveness when examining the intuitive evaluation by a respondent, it is more advisable to present the second part of a proverb requesting him to fill in its beginning. Such research has to involve a significantly higher number of respondents. A questionnaire should be userfriendly and eligible for filling out in a comfortable manner. Our on-line application 
has proved to be very successful. Extensive sets of proverbs may be tested by using it and moreover, an on-line questionnaire enables to address much more speakers and to select and qualify a sufficiently representative sample of prospective respondents. That reduces the greatest problem of paremiological experiments, namely that a small group of informants does not accurately represent the population in terms of demography and sociolinguistics.

Findings from such a questionnaire would give an insight into the current paremiology. They may serve as a basis both for wider sociolinguistic research and for their lexicographic description. Ascertaining the awareness of proverbs and their occurrence in huge corpora offers a coherent insight into the formal aspects of existing proverbs. The use of formal language may, within the framework of corpus linguistic, lead to improved analysis of the form of the set phrases and the idiomatics as well. The corpus analysis may also give answer to the question of paremiological neology. With respect to paremiology, it may bring about a new way of the description of paremiological models. The gathered information on outdated and unknown proverbs would serve as a source material for historical paremiological research.

Paremiodidactics is another field that may benefit from such research. Based on the data, there may be a paremiological optimum and various paremiological minima created, usable in teaching of mother tongue and foreign languages. The results would also contribute to international paremiological research as an empirically proven basis for the purposes of contrastive paremiology. The empirical and corpus based research will allow a fully new approach to the comparison and typology of equivalence in contrastive paremiology.

\section{References}

Albig, W. (1931). Proverbs and Social Control. Sociology and Social Research 15, 527-535.

Buhofer, A. (1980). Der Spracherwerb von phraseologischen Wortverbindungen. Eine psycholinguistische Untersuchung an schweizerdeutschem Material. Frauenfeld: Verlag Hueber.

Cacciari, Ch. \& Glucksberg, S. (1991). Understanding Idiomatic Expressions: The Contribution of Word Meanings. In G. B. Simpson (Ed.), Understanding Word and Sentence (pp. 217-240). Amsterdam: Elsevier.

Cacciari, Ch. \& Tabossi, P. (1993). Idioms: Processing Structure, and Interpretation. Hilsdale \& New Jersey: Lawrence Erlbaum Associates.

Čermák F. (2003). Paremiological Minimum of Czech: The Corpus Evidence. In H. Burger, A. Häcki Bufofer \& G. Greciano (Eds.), Flut von Texten - Vielfalt der Kulturen. Ascona 2001 zur Methodologie und Kulturspezifik der Phraseologie (pp. 15-31). Hohengehren: Schneider Verlag.

Chlosta, Ch. \& Grzybek, P. (1997). Sprichwortkenntnis in Deutschland und Österreich. Empirische Ergebnisse zu einigen mehr oder weniger gewagten Hypothesen. In R. Muhr \& R. Schrodt (Eds.), Österreichisches Deutsch und andere nationale Varietäten plurizentrischer Sprachen in Europa. Empirische Analysen (pp. 243-261). Wien: Verlag Hölder-Pichler-Tempsky. 
Chlosta, Ch. \& Grzybek, P. (2004). Was heißt eigentlich „Bekanntheit“ von Sprichwörtern? In Cs. Földes (Ed.), Res humanae proverbiorum et sententiarum. Ad honorem Wolfgangi Mieder (pp. 37-57), Tübingen: Gunter Narr.

Chlosta, Ch., Grzybek, P. \& Roos, U. (1994). Wer kennt denn heute noch den Simrock? Ergebisse einer emprischen Untersuchung zur Bekanntheit deutscher Sprichwörter in traditionellen Sammlungen. In Ch. Chlosta, P. Grzybek \& E. Piirainen (Eds.), Sprachbilder zwischen Theorie und Praxis (pp. 31-60). Bochum, Universitätsverlag Brockmeyer.

Cox, L. H. (1997). Beobachtungen zur standardsprachlichen Sprichwortkompetenz deutscher Universitätsstudent(inn)en. In R.-E. Mohrmann, V. Rodekamp \& D. Sauermann (Eds.), Volkskunde im Spannungsfeld zwischen Universität und Museum - Festschrift zum 65. Geburtstag von Hinrich Siuts, Band 95 (pp. 43-65). Münster/New York/München/Berlin: Waxmann.

Ďurčo, P. (1990). Die Interpretation der Idiome aus psycholinguistischer Sicht. Folia Linguistica. Acta Societatis Linguisticae Europae 24/1-2, 1-22.

Ďurčo, P. (1992). Das Sprachwissen und figurative Bedeutung. In E. Krošláková (Ed.), Die Phraseologie als Intensivierungsfaktor der Kommunikation. Výskumné materiály 34 (pp. 69-85). Nitra: Pedagogická fakulta.

Ďurčo, P. (1998). Experimentelle Untersuchung der individuellen Bedeutung von Phraseologismen. In W. Eismann (Ed.), EUROPHRAS'95 - Europäische Phraseologie im Vergleich. Gemeinsames Erbe und kulturelle Vielfalt (pp. 165-174). Bochum: Universitätsverlag Brockmeyer.

Ďurčo, P. (2001). Bekanntheit, Häufigkeit und lexikographische Erfassung von Sprichwörtern. Zu parömiologischen Minima für DaF. In A. Häcki Buhofer, H. Burger \& L. Gautier (Eds.): Phraseologiae Amor. Aspekte europäischer Phraseologie (pp. 99-106). Hohengehren: Schneider Verlag.

Ďurčo, P. (2002). Unterschiede in der (Un)kenntnis von Sprichwörtern in verschiedenen Lebensaltern. In A. Häcki Buhofer (Ed.): Spracherwerb und Lebensalter (pp. 293-304). Tübingen/Basel: A. Francke Verlag.

Ďurčo, P. (2003). Empirische Daten zur Sprichwörtervariabilität. In H. Burger, A. Häcki Buhofer \& G. Gréciano (Eds.), Flut von Texten - Vielfalt der Kulturen. Ascona 2001 zur Methodologie und Kulturspezifik für Phraseologie (pp. 83-95). Hohengehren: Schneider Verlag.

Ďurčo, P. (2004). Slovak Proverbial Minimum: The Empirical Evidence. In Cs. Földes (Ed.), Res humanae proverbiorum et sententiarum. Ad honorem Wolfgangi Mieder (pp. 59-69). Tübingen: Gunter Narr.

Ďurčo, P. (2005a). Sprichwörter in der Gegenwartssprache. Trnava: Univerzita sv. Cyrila a Metoda v Trnave.

Ďurčo, P. (2005b). Paremiologické minimum slovenčiny. Výsledky a porovnania. In R. Blatná \& V. Petkevič (Eds.), Jazyky a jazykověda. Sborník k 65. narozeninám prof. PhDr. Františka Čermáka, DrSc. (pp. 45-61). Praha: Ústav Českého národního korpusu.

Ďurčo, P. (2005c): Empirisch- und korpusbasierte Untersuchungen der Sprichwörter. Zeitschrift für germanistische Sprach- und Literaturwissenschaft in der Slowakei 3, 47-57.

Ďurčo, P. (2006): Methoden der Sprichwortanalysen oder Auf dem Weg zum Sprichwörteroptimum. In A. Häcki Buhofer \& H. Burger (Eds.), Phraseology in Motion. Methoden und Kritik. Akten der Internationalen Tagung zur Phraseologie Basel, 2004. Hohengehren: Schneider Verlag.

Ďurčo, P. (2007). Paremiologické optimum slovenčiny. In W. Chlebda (Ed.), Frazeologia a językowe obrazy świata przełomu wieków (pp. 171-177). Opole: Uniwersytet Opolski.

Ďurčo, P. (2008). Variabilität der festen Wortkomplexe in Wörterbüchern und Texten. Zur Typologie der textuellen Variabilität von propositionalen Idiomen. In V. Jesenšek \& A. Lipavic Oštir (Eds.), Wörterbuch und Übersetzung. 4. Internationales Kolloquium zur Lexikographie und Wörterbuchforschung. Universität Maribor. 20. bis 22. Oktober 2006 (pp. 131-143). Hildesheim/ Zürich/New York: Georg Olms Verlag. 
Ďurčo, P. (2012). Diasystematische Differenzen von Sprichwörtern aus der Sicht der kontrastiven Parömiologie. In K. Steyer (Ed.), Sprichwörter multilingual. Theoretische, empirische und angewandte Aspekte der modernen Parömiologie (pp. 357-377). Tübingen: Narr Verlag.

Ďurčo, P. (2013). Extensionale und intensionale Äquivalenz in der Phraseologie Am Beispiel von deutschen und slowakischen Sprichwörtern. In N. Kübler, J.-M. Benayoun \& J.-P. Zougbo (Eds.): Tous les chemins mènent à Paris Diderot. Actes du Colloque international de Parémiologie, Université Paris Diderot 29 juin-2 juillet 2011 (in press). Hohengehren: Schneider Verlag.

Ďurčo, P. \& Meterc, M. Empirične paremiološke raziskave tipov ekvivalentnosti in suprasemantičnih razlik v slovenščini in slovaščini. Slavia centralis (in press).

Ďurčo, P. \& Steyer, K. (2010): Vorwort zur Sprichwortdatenbank. In: Datenbank des EU-Projekts SprichWort. www.sprichwort-plattform.org/sp/Vorwort

Everaert, M., van der Linden, E. J., Schenk, A. \& Schreuder, R. (Eds.) (1995). Idioms: Structural and Psychological Perspectives. Hillsdale/New Jersey: Lawrence Erlbaum Associates.

Gibbs, R. W. (1985). On the Process of Understanding Idioms. Journal of Psycholinguistic Research $14 / 5,465-472$.

Gibbs, R. W. \& Nayak, N. P. (1989). Psycholinguistic Studies on the Syntactic Behavior of idioms. Cognitive Psychology 21/1, 100-138.

Gibbs, R. W. \& O`Brien, J. E. (1990). Idioms and Mental Imagery: The Metaphorical Motivation for Idiomatic Meaning. Cognition 36, 35-68.

Grzybek. P. (1984). Bibliographie der Arbeiten Permjakovs. Ars Semiotica 7/3-4. Tübingen: Gunter Narr, 203-214.

Grzybek, P. (1991). Sinkendes Kulturgut. Eine empirische Pilotstudie zur Bekanntheit deutscher Sprichwörter. Wirkendes Wort 2, 239-264.

Grzybek, P. (1992). Probleme der Sprichwort-Lexikographie (Parömiographie): Definition, Klassifikation, Slektion. In G. Meder \& A. Dörner (Eds.), Worte, Wörter, Wörterbücher. Lexikographische Beiträge zum Essener Linguistischen Kolloquium (pp. 195-223). Tübingen: Gunter Narr.

Grzybek, P. (1998). Komparative und interkulturelle Parömiologie. Methodologische Bemerkungen und empirische Befunde. In W. Eismann (Ed.), EUROPHRAS 95: Europäische Phraseologie. Gemeinsames Erbe und kulturelle Vielfalt (pp. 263-282). Bochum: Universitätsverlag Brockmeyer.

Grzybek, P. (2012). Facetten des parömiologischen Rubik-Würfels. In K. Steyer (Ed.), Sprichwörter multilingual. Theoretische, empirische und angewandte Aspekte der modernen Parömiologie (pp. 99-138). Tübingen: Gunter Narr.

Grzybek, P. \& Chlosta, Ch. (1993). Grundlagen der empirischen Parömiologie. Proverbium. Yearbook of International Proverb Scholarship 10, 89-128.

Grzybek, P., Chlosta, Ch. \& Roos, U. (1994). Ein Vorschlag zur Klassifikation von Sprichwortvarianten in der empirischen Sprichwortforschung. In B. Sandig (Ed.), Europhras 1992. Tendenzen der Phraseologieforschung (pp. 221-256). Bochum: Universitätsverlag.

Grzybek, P., Škara, D. \& Heyken, Z. (1993). Der Weisheit der Gasse auf der Spur. Eine empirische Pilotstudie zur Bekanntheit kroatischer Sprichwörter. Zeitschrift für Balkanologie 29/2, 85-98.

Haas, H. A. (2008). "Proverb Familiarity in the United Sates: Cross-Regional Comparisons of the Paremiological Minimum." Journal of American Folklore 121/481, 319-347.

Häcki Buhofer, A. (1989). Psycholinguistische Aspekte in der Bildhaftigkeit von Phraseologismen. In G. Gréciano (Ed.), Europhras 88. Phraséologie Contrastive. Actes du Colloque International Klingenthal - Strasbourg, 12-16 mai 1988 (pp. 165-175). Strasbourg: Université des Sciences Humaines.

Häcki Buhofer, A. (1997). Phraseologismen im Spracherwerb. In R. Wimmer \& F. J. Berens (Eds.), Wortbildung und Phraseologie (pp. 209-232). Tübingen: Gunter Narr.

Häcki Buhofer, A. (1999). Psycholinguistik der Phraseologie. In N. F. Bravo, I. Behr \& C. Rozier (Eds.), Phraseme und typisierte Rede (pp. 63-75). Tübingen: Gunter Narr. 
Häcki Buhofer, A. \& Burger, H. (1992). Gehören Redewendungen zum heutigen Deutsch? Fremdsprachen Lehren und Lernen 21, 11-32.

Häcki Buhofer, A. \& Burger, H. (1994). Phraseologismen im Urteil von Sprecherinnen und Sprechern. In B. Sandig (Ed.): Europhras 92: Tendenzen der Phraseologieforschung (pp. 1-33. Bochum: Universitätsverlag Brockmeyer.

Hirsch, E. D. (1987). Cultural Literacy. What Every American Needs to Know. With an Appendix, What Literate Americans Know, by E. D. Hirsch, J. Kett and j. Trefil. Boston: Houghton Mifflin Company.

Hirsch, E. D., Kett, J. \& Trefil, J. (1988). The Dictionary of Cultural Literacy: What Every American Needs to Know. Boston: Houghton Mifflin Company.

Kačala, J. \& Pisárčiková, M. (Eds.) (1997). Krátky slovník slovenského jazyka. $3^{\text {rd }}$ edition, Bratislava: Veda.

Kuusi, M. (1985). Proverbia septentrionalia. 900 Balto-Finnic Proverb Types with Russian, Baltic, German and Scandinavian Parallels. Helsinki: Suomalainen Tiedeakatemia.

Meterc, M. (in press). Online questionnaire providing information on most well-known and well-understood proverbs in Slovene language. In V. Jesenšek et all (Eds.), EUROPHRAS 2012 Maribor. Phraseologie und Kultur, Maribor 27.-31. 8. 2012.

Mieder, W. (1994). Paremiological Minimum and Cultural Literacy. In W. Mieder (Ed.), Wise Words. Essays on the Proverb (pp. 297-316). New York/London: Garland Publishing, Inc.

Miko, F. a kol. (1989). Frazeológia $v$ škole. Bratislava: Slovenské pedagogické nakladatel'stvo.

Mlacek, J. \& Profantová, Z. (1996). Slovenské príslovia a porekadlá. Výber zo zbierky A. P. Zátureckého. Bratislava: Nestor.

Mokijenko, V. M. (2012). Russissches parömiologisches Minimum: Theorie oder Praxis? In: K. Steyer (Ed.), Sprichwörter multilingual. Theoretische, empirische und angewandte Aspekte der modernen Parömiologie (pp. 79-98). Tübingen: Gunter Narr.

Permjakov, G. L. (1973). On the paremiological level and premiological minimum of language. Proverbium 22, 862-863.

Permjakov, G. L. (1982). K voprosu o paremiologičeskom minimume. In E. M. Vereščagin (Ed.), Slovari i lingvostranovedenije (pp. 131-137). Moskva: Russkij jazyk.

Permjakov, G. L. (1985). 300 allgemeingebräuchliche Sprichwörter und sprichwörtliche Redensarten. Ein illustriertes Nachschlagewerk für Deutschsprechende. Moskau/Leipzig: Russkij jazyk \& VEB Verlag Enzyklopädie.

Permjakov, G. L. (1989). On the Question of a Russian Paremiological Minimum. In: Proverbium 6, 91-102.

Permjakov, G. L. \& Vlachov, S. I. (1986). 300 obščeupotrebitel'nych poslovic i pogovorok (dla govorjaščich na bolgarskom jazyke). Moskva: Russkij jazyk.

Schindler, F. (1993). Das Sprichwort im heutigen Tschechischen. Empirische Untersuchung und semantische Beschreibung. München: Otto Sagner.

Smiešková, E. (1977). Malý frazeologický slovník. Bratislava: Slovenské pedagogické nakladatel'stvo.

Steyer, K. (2012a): Sprichwortstatus, Frequenz, Musterbildung. Parömiologische Fragen im Lichte korpusmethodischer Empirie. In Steyer 2012b.

Steyer, K. (Ed.) (2012b): Sprichwörter multilingual. Theoretische, empirische und angewandte Aspekte der modernen Parömiologie. Tübingen: Gunter Narr.

Steyer, K. \& Hein, K. (2010): Deutsche Sprichwortartikel. In: Datenbank des EU-Projekts SprichWort. www.sprichwort-plattform.org/sp/Sprichwort

Steyer, K. \& Ďurčo, P. (2013): Ein korpusbasiertes Beschreibungsmodell für die elektronische Sprichwortlexikografie. In: N. Kübler, J.-M. Benayoun \& J.-P. Zougbo (Eds.): Tous les chemins mènent à Paris Diderot. Actes du Colloque international de Parémiologie, Université Paris Diderot 29 juin-2 juillet 2011. (in press) Hohengehren: Schneider Verlag. (preprint: http://www.owid.de/extras/sprw/SW_Modell_steyer_durco.pdf). 
Tóthné Litovkina, A. (1996). Conducting a Paremiological Experiment in Hungary. Proverbium: Yearbook of International Proverb Scholarship 13, 161-183.

Vargha, K. \& Litovkina, A. T. (2007). Proverbs is as Proverb Does: A Preliminary Analysis of a Survey on the Use of Hungarian Proverbs and Anti-Proverbs. Acta Ethnographica Hungarica 52, 135-155.

Záturecký, A. P. (1974). Slovenské príslovia, porekadlá a úslovia. 3. vydanie. Ed. M. Kosová. Bratislava: Tatran. 